Tohoku J. exp. Med., 1986, 148, 303-312

\title{
Effects of Paraquat on Macromolecule Synthesis in Cultured Pneumocytes
}

\author{
Kotaro Saito \\ Division of Neonatology, Department of Pediatrics, The \\ University of Texas Health Science Center at Dallas, 5323 \\ Harry Hines Boulevard, Dallas, TX 75235, USA
}

SaIto, K. Effects of Paraquat on Macromolecule Synthesis in Cultured Pneumocytes. Tohoku J. exp. Med., 1986, 148 (3), 303-312 — The effects of paraquat $(\mathrm{PQ})$ on cell growth, DNA, RNA and protein synthesis and on superoxide dismutase (SOD) activity were investigated in cultured pneumocytes of type II cell origin and human embryonic fibroblast cells of the lung. The incorporation of ${ }^{3} \mathrm{H}$-thymidine, ${ }^{3} \mathrm{H}$-uridine and ${ }^{14} \mathrm{C}$-leucine into DNA, RNA and protein, respectively, were all reduced to $25 \%-70^{-} \%$ of the control by $\mathrm{PQ}$ at $10^{-3} \mathrm{M}$, but not at $10^{-5}$ M nor $10^{-7} \mathrm{M}$. The activity of SOD in the cells was increased to $130 \%-270^{\circ} \%$ by $10^{-3} \mathrm{M}$ of PQ. Among the cells studied, A-549 cells, which were most resistant to the inhibitory effect of PQ on cell growth and the synthesis of DNA, RNA and protein had the highest induction of SOD activity by PQ. In contrast, L-2 cells in which the cell growth and the synthesis of nucleic acids and protein were most inhibited had the lowest induction of SOD activity by PQ. These results indicate that nucleic acids and protein synthesis are possible targets for lethal effects of PQ in the pulmonary cells, and that the specificity of $\mathrm{PQ}$ toxicity in pulmonary cell lines might be related to the ability of induction of SOD by PQ. _ _ paraquat; superoxide dismutase; nucleic acid; protein; pneumocytes

Paraquat (1, 1'-dimethyl-bipyridilium 4, 4'-dichloride, PQ), a bipyridilium herbicide, is known to cause pulmonary injury including fatal fibrosis after exposure in human and animals (Cavalli and Fletcher 1977; Dasta 1978; Haley 1979 ; Parkinson 1980). The biological mechanism of PQ toxicity in the lung is believed to be related to the cyclic oxidation-reduction of $\mathrm{PQ}$ which leads to contineous production of cytotoxic oxygen free radicals including superoxide anion and hydrogen peroxide (Bus et al. 1977; Haley 1979; Smith et al. 1979). In the past, several hypotheses for the mechanisms of the characteristic pulmonary toxicity of $\mathrm{PQ}$ have been proposed, i.e., peroxidation of lipids of lung microsomes (Trush et al. 1981; Frank et al. 1982), an alteration in nucleic acid metabolism (Ross et al. 1979), an imbalance in reduced pyridine nucleotide concentration (Rose et al. 1976), the disruption of subcellular energy metabolism (Montgomery et al. 1982) and the inhibition of phospholipid metabolism (Saito et al. 1982). However, the effect of $\mathrm{PQ}$ on the synthesis of nucleic acids and protein in the 
pulmonary cells is not well understood. It has been suggested that, in alveolar region, type II cells proliferate and differentiate to type I cells after alveolar injury (Kauffman 1980). The morphological evaluation of the PQ treated-lung revealed the characteristic fibrosis (Schoenberger et al. 1984), but the mechanisms by which $\mathrm{PQ}$ causes fibrotic change in the lung and the biochemical effects of $\mathrm{PQ}$ on pulmonary fibroblast cells have not been studied enough.

In the present study, the effects of $\mathrm{PQ}$ on cell growth and on the incroporation of precursors into deoxyribonucleic acid (DNA), ribonucleic acid (RNA) and protein of estabolished cell lines of type II pneumocyte origin of three species (rat, feline and human) of different stages in development (embryonic and adult) were examined. The effects of PQ on the incorporation of precursors into DNA, RNA and protein of human lung fibriblast cells were also examined.

The detoxification of superoxide anion is recognized to be accompanied by increases of superoxide dismutase activity (Montgomery 1977). The intracellular induction of superoxide dismutase by $\mathrm{PQ}$ was examined in three cell lines of type II pneumocyte origin to study any correlation between the induction of SOD activity and the protection from PQ toxicity.

\section{Materials and Methods}

Cell culture. Four established pulmonary cell lines, L-2 cells derived from adult rat lung (Douglas and Kaighn 1974), AK-D cells derived from embryonic feline lung (Kniazeff et al. 1976), A-549 cells derived from adult human lung (Lieber et al. 1976) and embryonic human lung cells of fibroblast (HEL) (Peterson et al. 1978), were obtained from American Type Culture Collection (Rockville, MD, USA). L-2 cells and AK-D cells were grown in F-12K culture medium containing $20 \%$ and $15 \%$ of fetal calf serum (FCS), respectively, A-549 cells and HEL cells were grown in Dulbecco's modified essential medium with Earle's salts (MEM) containing $10 \%$ FCS in plastic tissue culture flasks at $37^{\circ} \mathrm{C}$. The tissue culture media were supplemented with $100 \mathrm{units} / \mathrm{ml}$ of penicillin $\mathrm{G}$ and $100 \mu \mathrm{g} / \mathrm{ml}$ of streptomycin.

$P Q$ effect on cell growth. The three cell lines of type II pneumocytes were cultured with $\mathrm{PQ}$ at $10^{-5} \mathrm{M}$ and $10^{-3} \mathrm{M}$ of for $6-7$ days $37^{\circ} \mathrm{C}$. The primary cell numbers were adjusted to $5 \times 10^{4}$ cells $/ \mathrm{ml}$. The cell numbers were determined in a hemocytometer at each $24 \mathrm{hr}$ after trypsinization with $0.125 \%$ trypsin and $0.02 \%$ ethylendiamine tetraacetic acid (EDTA). Culture media were changed at 2, 4 and 6 days in culture and PQ was also added to the new media.

$P Q$ effect on nucleic acids and protein synthesis. Cells were incubated with $\mathrm{PQ}$ at $10^{-7}$ M, $10^{-5} \mathrm{M}$ and $10^{-3} \mathrm{M}$ at $37^{\circ} \mathrm{C}$ for $24 \mathrm{hr}$. At the beginning of the incubation, $0.05 \mu \mathrm{Ci} / \mathrm{ml}$ of each of ${ }^{3} \mathrm{H}$-thymidine (specific activity; $2 \mathrm{Ci} /$ mmole, ${ }^{3} \mathrm{H}$-TdR), ${ }^{3} \mathrm{H}$-uridine (specific activity ; $2 \mathrm{Ci} / \mathrm{mmole},{ }^{3} \mathrm{H}-\mathrm{UdR}$ ) and ${ }^{14} \mathrm{C}$-leucine (specific activity; $50 \mathrm{mCi} / \mathrm{mmole},{ }^{14} \mathrm{C}$ $\mathrm{LcR}$ ) were added to the culture media. At the end of incubation, cells were washed three times with ice cold Dulbecco's phosphate buffered saline solution (PBS), pH 7.4. The cells were treated with ice cold 10\% trichloroacetic acid (TCA) for 10 min and then $5 \%$ TCA for 20 min at room temperature. The cells were disolved in $1 \mathrm{~N} \mathrm{NaOH}$ at room temperature. Aliquots were removed to measure protein concentration by the method of Lowry (Lowry et al. 1951). Protein concentration was determined relative to calf serum albumin. Other aliquots were neutralized with $1 \mathrm{~N} \mathrm{HCl}$ prior to measurement of the radioactivity by scintillation counting technique. The radio activity of the cells was expressed as counts per minute $(\mathrm{cpm})$ per mg protein. 
$P Q$ effect on $S O D$ induction. The induction of superoxide dismutase (SOD) by $P Q$ was examined according to the method of Hassan and Fridovich (1977). The cells were incubated with $\mathrm{PQ}$ at $10^{-3} \mathrm{M}$ for $24 \mathrm{hr}$ at $37^{\circ} \mathrm{C}$. At the end of incubation, cells were washed with ice cold tissue culture medium three times collected in ice cold PBS by scraping with rubber policeman. The cells were sonicated in ice bath for $30 \mathrm{sec}$. An aliquot was taken to measure protein concentration and the other aliquots were utilized to measure SOD activity. The SOD activity was expressed to units (U) per mg protein and was standardized with calf erythrocyte SOD. The SOD activity in enucleated cells was also examined. The enucleation procedure was performed with the method of Clark and Greenspan (1979). Briefly, A-549 cells were treated with $10 \mu \mathrm{g} / \mathrm{ml}$ of cytochalasin B at $37^{\circ} \mathrm{C}$ for $10 \mathrm{~min}$ and centrifuged at $34^{\circ} \mathrm{C}$ for $40 \mathrm{~min}$ at $3,000 \times \mathrm{g}$. The efficiency of enucleation was determined with microscopical observation after staining by May-Grünbald-Giemsa staining solution. The enucleated cells were incubated with $\mathrm{PQ}$ at $10^{-3} \mathrm{M}$ at $37^{\circ} \mathrm{C}$ for $24 \mathrm{hr}$ and $48 \mathrm{hr}$. The SOD activity and protein concentration were determined at each $24 \mathrm{hr}$ and $48 \mathrm{hr}$ with the methods descrived above.

Statistic analysis of the data was performed by Student's $t$ test.

Tissue culture suppleis were obtained from GIBCO (Gland Island, NY, USA). The radioactive precursors were obtained from New England Nuclear (Boston, MA, USA). The other chemical reagents were purchased from Sigma Chem. Co. (St. Louis, MO, USA).

\section{Results}

Effect of $P Q$ on cell growth. The cell growth of three cell lines, L-2 cells, AK-D cells and A-549 cells, were markedly inhibited by PQ at $10^{-3} \mathrm{M}$. In L-2

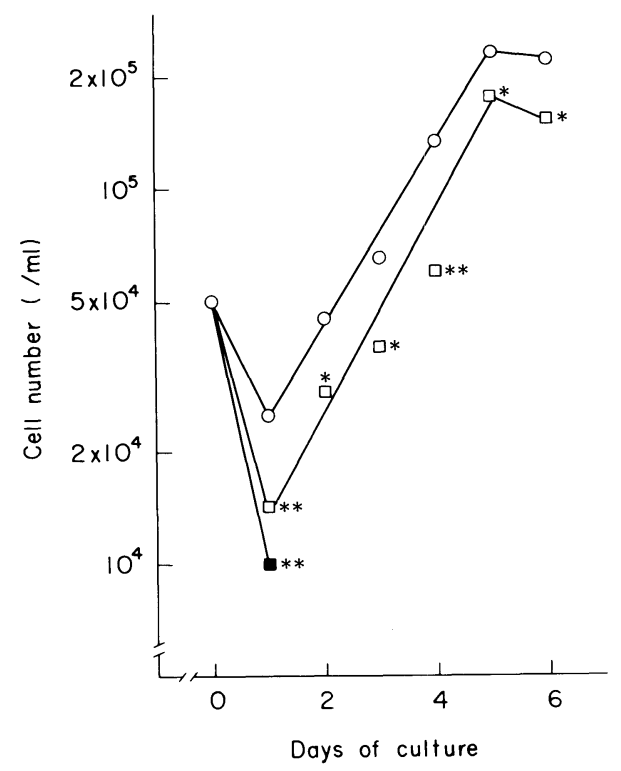

Fig. 1. Effect of $\mathrm{PQ}\left(10^{-3} \mathrm{M}\right.$ and $\left.10^{-5} \mathrm{M}\right)$ on the cell growth of L-2 cells. Cells were cultured with or without $\mathrm{PQ}$ for 6 days at $37^{\circ} \mathrm{C}$. O, control; $\square, \mathrm{PQ}\left(10^{-5} \mathrm{M}\right)$; $\mathbf{- ,} \mathrm{PQ}\left(10^{-3} \mathrm{M}\right)$. Each point indicates the average cell number of 4 samples. ${ }^{*} p<0.05 ;{ }^{* *} p<0.01$. 
cells, appreciable numbers of the viable cells by the treatment of trypsin to count the cell numbers were not detected after 2 days in culture. Addition of $10^{-5} \mathrm{M}$ $\mathrm{PQ}$ also resulted in the inhibition of growth of L-2 cells in culture (Fig 1). In A-549 cells, control cells were grown to $8.2 \times 10^{5}$ cells $/ \mathrm{ml}$ by 6 days, while the cell numbers in the presence of $10^{-3} \mathrm{MPQ}$ diminished to $8.4 \times 10^{3}$ cells $/ \mathrm{ml}$ by 6 days in culture. At $10^{-5} \mathrm{M}, \mathrm{PQ}$ did not show the inhibitory effect on cell growth of A-549 cells in culture (Fig. 2). Appreciable numbers of AK-D cells in culture were not detected by trypsinization for counting the cell numbers after 4 day in the presence of $10^{-3} \mathrm{M} P Q$. PQ at $10^{-5} \mathrm{M}$ also inhibited the growth of AK-D cells at 6 and 7 days in culture (data are not shown).

Effect of $P Q$ on nucleic acids and protein synthesis. The incorporation of ${ }^{3} \mathrm{H}-\mathrm{TdR},{ }^{3} \mathrm{H}-\mathrm{UdR}$ and ${ }^{14} \mathrm{C}-\mathrm{LcR}$ into acid insoluble fractions of DNA, RNA and protein, respectively, were significantly decreased by $10^{-3} \mathrm{M} P \mathrm{P}$ in all cell lines examined (Table 1). Comparing the effect of $10^{-3} \mathrm{M} P Q$ on the incorporation of precursors into the cells of type II pneumocytes origin, the incorporation of ${ }^{3} \mathrm{H}-\mathrm{TdR}$ into DNA was reduced to $39 \%$ in L-2 cells and $76 \%$ in AK-D cells. That

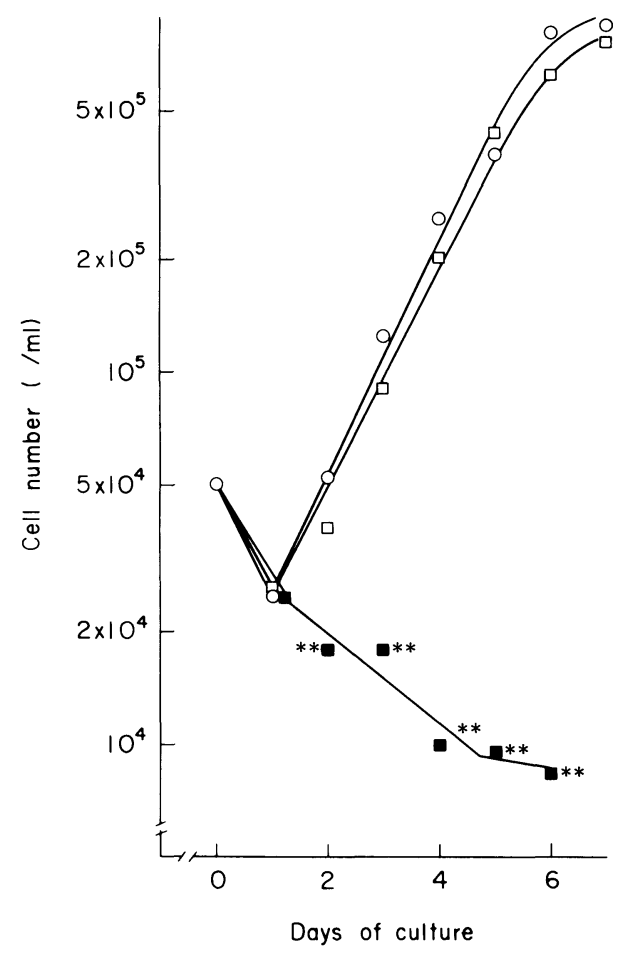

Fig. 2. Effect of $\mathrm{PQ}\left(10^{-3} \mathrm{M}\right.$ and $\left.10^{-5} \mathrm{M}\right)$ on the cell growth of $\mathrm{A}-549$ cells. Cells were cultured with or without $\mathrm{PQ}$ for 7 days at $37^{\circ} \mathrm{C}$.

$\bigcirc$, control; 口, $\mathrm{PQ}\left(10^{-5} \mathrm{M}\right)$; $\mathbf{-}, \mathrm{PQ}\left(10^{-3} \mathrm{M}\right)$. Each point indicates the average cell number of 3 samples.

${ }^{* *} p<0.01$. 
TABle 1. Effect of $P Q\left(10^{-3} M, 10^{-5} M\right.$ and $\left.10^{-7} M\right)$ on ${ }^{3} \mathrm{H}-T d R,{ }^{3} \mathrm{H}-U d R$ and ${ }^{14} \mathrm{C}-\mathrm{LcR}$ incorporation into the cells

\begin{tabular}{clccc}
\hline & & ${ }^{3} \mathrm{H}-\mathrm{TdR}$ & ${ }^{3} \mathrm{H}-\mathrm{UdR}$ & ${ }^{14} \mathrm{C}-\mathrm{LcR}$ \\
\hline AK-D cells & Control & $113.9 \pm 14.0$ & $101.1 \pm 3.2$ & $134.4 \pm 8.4$ \\
& $\mathrm{PQ}\left(10^{-3} \mathrm{M}\right)$ & $86.4 \pm 12.8^{*}$ & $55.1 \pm 12.2^{* *}$ & $104.1 \pm 13.6^{* *}$ \\
& $\mathrm{PQ}\left(10^{-5} \mathrm{M}\right)$ & $96.6 \pm 26.5$ & $100.2 \pm 14.1$ & $139.0 \pm 8.5$ \\
& $\mathrm{PQ}\left(10^{-7} \mathrm{M}\right)$ & - & - & - \\
\hline L-2 cells & Control & $297.4 \pm 17.4$ & $416.5 \pm 5.5$ & $279.5 \pm 6.6$ \\
$(\mathrm{n}=4)$ & $\mathrm{PQ}\left(10^{-3} \mathrm{M}\right)$ & $114.6 \pm 12.9^{* *}$ & $89.8 \pm 4.3^{* *}$ & $137.3 \pm 22.6^{* *}$ \\
& $\mathrm{PQ}\left(10^{-5} \mathrm{M}\right)$ & $291.1 \pm 10.2$ & $397.9 \pm 21.5$ & $261.9 \pm 7.6$ \\
& $\mathrm{PQ}\left(10^{-7} \mathrm{M}\right)$ & $283.7 \pm 21.3$ & $431.8 \pm 11.9$ & $269.7 \pm 7.4$ \\
\hline A-549 cells & Control & $743.6 \pm 63.6$ & $278.1 \pm 11.9$ & $209.7 \pm 8.6$ \\
$(\mathrm{n}=4)$ & $\mathrm{PQ}\left(10^{-3} \mathrm{M}\right)$ & $357.6 \pm 12.5^{* *}$ & $168.5 \pm 8.1^{* *}$ & $169.0 \pm 7.1^{* *}$ \\
& $\mathrm{PQ}\left(10^{-5} \mathrm{M}\right)$ & $734.8 \pm 57.0$ & $256.1 \pm 19.6$ & $179.1 \pm 13.2$ \\
& $\mathrm{PQ}\left(10^{-7} \mathrm{M}\right)$ & $792.0 \pm 71.2$ & $290.9 \pm 8.4$ & $248.3 \pm 26.3$ \\
\hline HEL cells & Control & $209.0 \pm 47.4$ & $160.6 \pm 1.8$ & $59.9 \pm 5.4$ \\
$(\mathrm{n}=3)$ & $\mathrm{PQ}\left(10^{-3} \mathrm{M}\right)$ & $56.4 \pm 14.4^{* *}$ & $65.7 \pm 21.2^{* *}$ & $19.2 \pm 2.1^{* *}$ \\
& $\mathrm{PQ}\left(10^{-5} \mathrm{M}\right)$ & $200.4 \pm 57.0$ & $149.5 \pm 10.2$ & $56.6 \pm 7.7$ \\
& $\mathrm{PQ}\left(10^{-7} \mathrm{M}\right)$ & $211.0 \pm 17.5$ & $166.9 \pm 4.7$ & $54.3 \pm 8.8$ \\
\hline
\end{tabular}

${ }^{*} p<0.05, \quad{ }^{* *} p<0.01$.

Cells were cultured with PQ $\left(10^{-3} \mathrm{M}, 10^{-5} \mathrm{M}\right.$ and $\left.10^{-7} \mathrm{M}\right)$ at $37^{\circ} \mathrm{C}$ for $24 \mathrm{hr}$.

The values given are means \pm S.D. of $\mathrm{cpm}\left(\times 10^{2}\right) / \mathrm{mg}$ protein.

TABLE 2. SOD activity induced by $P Q\left(10^{-3} \mathrm{M}\right)$ in the cells for $24 \mathrm{hr}$

\begin{tabular}{lccc}
\hline & Control & PQ $\left(10^{-3} \mathrm{M}\right)$ & $\%$ Induction \\
\hline A-549 cells & $0.88 \pm 0.11$ & $2.40 \pm 0.42^{* *}$ & $272.4 \%$ \\
AK-D cells & $1.69 \pm 0.19$ & $2.65 \pm 0.23^{*}$ & $156.8 \%$ \\
L-2 cells & $3.02 \pm 0.24$ & $4.12 \pm 0.57^{*}$ & $136.4 \%$ \\
\hline
\end{tabular}

${ }^{*} p<0.05, \quad{ }^{* *} p<0.01$

Cells were cultured with $10^{-3} \mathrm{M}$ of $\mathrm{PQ}$ at $37^{\circ} \mathrm{C}$ for $24 \mathrm{hr}$.

The values given are mean \pm s.D. of SOD activity (units/mg protein) of 4 samples of each.

of ${ }^{3} \mathrm{H}-\mathrm{UdR}$ into RNA was reduced to $22 \%$ in L-2 cells and $61 \%$ in A-549 cells. L-2 cells seemed to be the most sensitive to the inhibitory effect of PQ on nucleic acids and protein synthesis, while A-549 cells were the most resistant. In HEL cells, addition of $10^{-3} \mathrm{M} \mathrm{PQ}$ resulted in inhibition of the incorporation of the radioactive precursors into $\mathrm{DNA}, \mathrm{RNA}$ and protein; the values were reduced to $27 \%, 41 \%$ and $32 \%$, respectively. At the concentration of $10^{-5} \mathrm{M}$ and $10^{-7} \mathrm{M}, \mathrm{PQ}$ did not show any significant inhibitory or stimulatory effects on the incorporation of the precursors into nucleic acids and protein of the cells examined (Table 1). 
TABLE 3. Effect of puromycin and actinomycin $D$ on SOD induction in $A-549$ cells by $P Q\left(10^{-3} \mathrm{M}\right)$ for $24 \mathrm{hr}$

\begin{tabular}{lcc}
\hline & SOD activity & $\%$ Induction \\
\hline Control & $0.93 \pm 0.09$ & $100.0 \%$ \\
PQ & $2.00 \pm 0.20$ & $214.0 \%$ \\
PQ + PM & $0.89 \pm 0.06^{* *}$ & $95.9 \%$ \\
PL + AcD & $0.74 \pm 0.05^{* *}$ & $79.5 \%$ \\
\hline
\end{tabular}

${ }^{* *} p<0.01$. $\mu \mathrm{g} / \mathrm{ml}$ ).

PM, puromycin $(200 \mu \mathrm{g} / \mathrm{ml}), \mathrm{AcD}$, actinomycin D (200

Cells were cultured with puromycin and actinomycin D in the presence of $\mathrm{PQ}$ at $37^{\circ} \mathrm{C}$ for $24 \mathrm{hr}$.

The values given are means \pm S.D. of SOD activity (units/ mg protein) of 3 samples of each. Comparison of means was performed between $\mathrm{PQ}$ cells vs $\mathrm{PQ}+\mathrm{PM}$ cells, and between $P Q$ cells and $P Q+A c D$ cells.

TABLE 4. SOD activity in enucleated A-549 cells

\begin{tabular}{llcc}
\hline & Time & SOD activity & $\%$ Induction \\
\hline $0 \mathrm{hr}$ & Control & $5.61 \pm 0.40$ & - \\
$24 \mathrm{hr}$ & Control & $4.55 \pm 0.38$ & $100.0^{\circ}$ \\
& $\mathrm{PQ}\left(10^{-3} \mathrm{M}\right)$ & $7.35 \pm 1.72^{*}$ & $161.5 \%$ \\
$48 \mathrm{hr}$ & $\mathrm{Control}$ & $3.98 \pm 0.89$ & $100.0 \%$ \\
& $\mathrm{PQ}\left(10^{-3} \mathrm{M}\right)$ & $9.45 \pm 1.45^{* *}$ & $273.4 \%$ \\
\hline
\end{tabular}

${ }^{*} p<0.05, \quad{ }^{* *} p<0.01$.

Cells were cultured for $24 \mathrm{hr}$ and $48 \mathrm{hr}$ with or without PQ $\left(10^{-3}\right.$ M) after enucleation. The values given are means \pm S.D. of SOD activity (units/mg protein) of 3 samples.

The statistic analysis was performed on the data between control and PQ cells at each $24 \mathrm{hr}$ and $48 \mathrm{hr}$.

The total protein concentrations of the cells in culture were decreased to $78 \%$ $85 \%$ at $24 \mathrm{hr}$ after the culture with $10^{-3} \mathrm{M}$ of $\mathrm{PQ}$, but $\mathrm{PQ}$ at $10^{-5} \mathrm{M}$ and $10^{-7} \mathrm{M}$ did not show any effects on protein concentration of the cells for $24 \mathrm{hr}$.

Effect of $P Q$ on $S O D$ induction. The induction of SOD activity in the presence of $\mathrm{PQ}$ was examined in three cell lines of type II pneumocyte origin. In these cells, SOD activity was significantly induced by $\mathrm{PQ}$ at $10^{-3} \mathrm{M}$ at $24 \mathrm{hr}$; an increase of $136 \%$ in L-2 cells, $157 \%$ in AK-D cells and $270 \%$ in A-549 cells (Table $2)$. Puromycin $(200 \mu \mathrm{g} / \mathrm{ml})$ and actinomycin-D $(200 \mu \mathrm{g} / \mathrm{ml})$, inhibitors of protein synthesis, removed the inductive effect of PQ on SOD in A-549 cells (Table 3). After incubation with puromycin and actinomycin D for $24 \mathrm{hr}$, the protein concentration of the cells in culture was decreased to $48 \%$ and $30 \%$ of control, respectively. The induction of SOD by $10^{-3} \mathrm{M} P Q$ in enucleated A-549 cells was 
also observed. The rate of enucleation by the treatment with cytochalacin B was greater than $99 \%$. SOD activity of the cells after addition of PQ $\left(10^{-3} \mathrm{M}\right)$ was increased to $162 \%$ at $24 \mathrm{hr}$ and $273 \%$ at $48 \mathrm{hr}$ (Table 4 ). The effect of puromycin and actinomycin D on the induction of SOD by PQ in enucleated cells was also examined. These reagents were toxic to the enucleated cells, and the cells died within $24 \mathrm{hr}$ after addition of these reagents. The appreciable concentration of protein cultured cells was not detected at $24 \mathrm{hr}$.

\section{Discussin}

Carmine et al. (1981) reported that PQ had no inhibitory effect on RNA and protein synthesis, but had inhibitory effect on DNA synthesis in macrophage-like cell line. Bell et al. (1976) failed to observe the inhibitory effect of PQ on thymidine incorporation into DNA of Vicia fava. However, it has been suggested $\mathrm{PQ}$ is selectively accumulated and is directly toxic to pulmonary cells of parenchyma (Ilet et al. 1974; Smith and Rose 1977; Seidenfeld et al. 1978). In previous experiments, $\mathrm{PQ}$, when added to medium at $10^{-3} \mathrm{M}$, accumulated into the cultured pneumocytes of type II cell origin to a maximum of $7.0 \mathrm{n} \mathrm{mol} / \mathrm{mg}$ protein in L-2 cells, 3-4 $\mathrm{n} \mathrm{mol} / \mathrm{mg}$ protein in AK-D cells and $3 \mathrm{n} \mathrm{mol} / \mathrm{mg}$ protein in A-549 cells for $1 \mathrm{hr}$ incubation at $37^{\circ} \mathrm{C}$ (Saito 1979, 1985). $\mathrm{PQ}$ also has an inhibitory effect on the growth of pulmonary cells in culture (Saito 1980). In the present study, PQ at $10^{-3} \mathrm{M}$ inhibited the incorporation of ${ }^{3} \mathrm{H}-\mathrm{TdR},{ }^{3} \mathrm{H}-\mathrm{UdR}$ and ${ }^{14} \mathrm{C}-\mathrm{LcR}$ into acid insoluble fractions of nucleic acids and protein, respectively, in all cell lines examined. Any specificity in the inhibitory effects of PQ on the incorporation of the precursors into nucleic acids and protein was not observed in the cells examined. The reasons for the differences in response to $\mathrm{PQ}$ toxicity between the cells examined and the cells in other reports are not clear. One of the reasons might be due to whether the cells have the ability to accumulate $\mathrm{PQ}$ during the incubation periods or not.

The mechanisms to prevent the damaging effects of lipid peroxidation initiated by oxidizing agents, such as PQ or oxygen, have been proposed. These include the conversion of superoxide radicals by superoxide disumutase to molecular oxygen and hydrogen peroxide (Hassan and Fridvich 1079). Hydrogen peroxide is further detoxificated by catalase. Glutathione peroxidase (selenium requiring) reduces unstable lipid hydroperoxide to stable lipid alcohols, preventing the formation of free radicals. In addition, glutathione reductase and glucose-6phosphate dehydrogenase $(\mathrm{G} 6 \mathrm{PDH})$ are considered to be very important in glutathione system. Reduced glutathione (GSH) provides reducing equivalents necessary for the removal of hydrogen peroxide and other toxic membrane lipid hydroperoxides through the action of glutathione peroxidase. GSH is replenished from oxidized glutathione by glutatione reductase usind NADPH generated by enzymes such as G6PDH (Bus et al. 1977). In the present study, the activity 
of SOD was significantly induced by $\mathrm{PQ}$ especially in A-549 cells. Considering the effects of $\mathrm{PQ}$ on cell growth or macromolecule synthesis and the induction of SOD in type II cell origin, the inhibitory effect of $\mathrm{PQ}$ on cell growth and macromolecule synthesis may be due to the balance between the rate of generation of oxygen radicals by $\mathrm{PQ}$ accumulated in the cells and the defence mechanisms in which SOD removes oxygen free radical anion from the cells. Puromycin and actinomycin D prevented the induction of SOD by PQ in the lung tissue. The basal SOD activity before induction by $\mathrm{PQ}$ each cell lines was different. One of the reasons may be due to the difference of total protein concentration in the cells. Of the various forms of superoxide dismutases, such as Fe-SOD, Cu-SOD and $\mathrm{Mn}-\mathrm{SOD}$, in the cells, it has been suggested that the induction of Mn-SOD by PQ and the tolerance of the tissues for PQ are related (Hassan and Fridovich 1979). The concentrations of Mn-SOD in each cells in normal condition are not known, but the increase in total SOD by PQ might be due to Mn-SOD.

Once the gene of SOD was found to be located in chromosome 6 in man-mouse somatic cell hybrids (Smith et al. 1978). In the present study, SOD induction by $\mathrm{PQ}$ in enucleated cells was observed. This result indicates that the gene of Mn-SOD in A-549 cells is located in cytoplasm. The activity of SOD per cell protein in enucleated cells was much higher than that in the intact cells. One of the reasons might be the loss of membrane structural protein disrupted by cytochalasin B in the process of enucleation (Saito 1982).

\section{References}

1) Bell, S.L., Schwalz, O.J. \& Hughes, K.W. (1976) Studies of herbicide paraquat. Effects on the cell cycle and DNA synthesis in Vicia fava. Canad. J. genet. Cytol., 18, 93-99.

2) Bus, J.S., Aust, S.D. \& Gibson, J.E. (1977) Lipid peroxidation as a proposed mechanism for paraquat toxicity. In: Biochemical Mechanisms of Paraquat Toxicity, edited by A.P. Autor, Academic Press, New York, pp. 157-172.

3) Carmine, E.L., Carchman, R.A. \& Borzelleca, L.F. (1981) Investigation into the mechanism of paraquat toxicity utilizing cell culture system. Toxicol. appl. Pharmacol., 58, 353-362.

4) Cavalli, R.D. \& Fletcher, K. (1977) An effective treatment for paraquat poisoning. In: Biochemical Mechanisms of Paraquat Toxicity, edited by A.P. Autor, Academic Press, New York, pp. 213-234.

5) Clark, J.L. \& Greenspan, S. (1979) Similarity in ornithine decarboxylase regulation in intact and enucleated 3T3 cells. Exp. Cell Res., 118, 253-260.

6) Dasta, J.F. (1978) Paraquat poisoning: A Review. J. Hosp. Pharmacol., 35, 13681372.

7) Douglas, W.H.J. \& Kaighn, M.E. (1974) Clonal isolation of differentiated rat lung cells. In Vitro, 10, 230.

8) Frank, L., Neriishi, K., Sio, R. \& Pascual, D. (1982) Protection from paraquatinduced lung damage and lethality in adult rats pretreated with clofibrate. Toxicol. appl. Pharmacol., 66, 269-277.

9) Haley, T.J. (1979) Review of the toxicology of paraquat (1, l'-dimethyl 4, 4'bipyridilium chloride). Clin. Toxicol., 14, 1-46. 
10) Hassan, H.M. \& Fridovich, I. (1977) Regulation of the synthesis of superoxide dismutase in Escherichia coli: Induction by methyl viologen. J. biol. Chem., 252, 7667-7672.

11) Hassan, H.M. \& Fridovich, I. (1979) Impermiability of the Escherichia coli cell envelope to superoxide radical. In : Chemical and Biochemical Aspects of Superoxide and Superoxide Dismutase, edited by J.V.Banister and H.A.O. Hill, Elsevier/North Holland, New York, pp. 57-71.

12) Ilet, K.F., Strip, B., Menard, R.H., Reid, W.D. \& Ilet, J.R. (1974) Studies on the mechanism of the lung toxicity of paraquat: Comparison of tissue distribution and biochemical parameters in rats and rabbits. Toxicol. appl. Pharmacol., 28, 216-226.

13) Kaufman, S.L. (1980) Cell proliferation in mammalian lung. Int. Rev. exp. Path., 22, 131-191.

14) Kniazeff, A.J., Stoner, G.D., Terry, L., Wagner, R.M. \& Hoppenstand, R.D. (1976) Characteristics of epitherial cells cultured from feline lung, Lab. Invest., 34, 495-500.

15) Liber, M., Smith, B., Szakal, A., Nelson-Ree, W. \& Torado, G. (1976) A contineous tumor-cell line from a human lung carcinoma with properties of type II alveolar epitherial cell. Int. J. Cancer, 17, 62-70.

16) Lowry, O.H., Rosebrough, N.J., Farr, A.L. \& Randall, R.J. (1951) Protein measurment with folin phenol reagent. J. biol. Chem., 193, 265-275.

17) Montgomery, M.R. (1977) Paraquat toxicity and pulmonary superoxide dismutase: An enzymic dificiency of lung microsomes. Res. Commun. Chem. path. Pharmacol., 16, $155-158$.

18) Montgomery, M.R., Furry, H., Gee, S.J. \& Krieger, R.I. (1982) Ascorbic acid and paraquat: Oxygen depletion with concurrent oxygen activation. Toxicol. appl. Pharmacol., 63, 321-329.

19) Parkinson, C. (1980) The changing pattern of paraquat poisoning in man, Histopath., 4, 171-183.

20) Peterson, W.D., Stulberg, C.S., Swanborg, N.K. \& Robinson, A.R. (1978) Glucose-6phosphate dehydrogenase isoenzymes in human cell culture : Determined by sucroseagar gel cell cellulose acetate zymozan. Proc. Soc. exp. Biol. Med., 128, 772-776.

21) Rose, M.S., Smith, L.L. \& Wyatt, I. (1976) The relevence of pentose phosphate pathway stimulation in rat lung to the mechanism of paraquat toxicity. Biochem. Pharmacol., 25, 1763-1767.

22) Ross, W.E., Block, E.R. \& Chang, R.Y. (1979) Paraquat-induced DNA damage in mammalian cells. Biochem. biophys. Res. Commun., 91, 1302-1308.

23) Saito, K. (1979) Paraquat accumulation by cultured lung cells. Pharmacol., 21, 218.

24) Saito, K. (1980) The effect of paraquat on phospholipid macromolecule synthesis in human lung cells. An abstract of 8th International Pharmacology Meeting, Tokyo.

25) Saito, K. (1982) Effects of amine substances on susceptibility of cells to agglutination by concanavalin A and on paracrystal formation by vinblastin in untransformed 3T3 cells. Tohoku J. exp. Med., 137, 91-99.

26) Saito, K. (1986) Effects of cation and some compounds on paraquat accumulation into cultured pneumocytes. Tohoku J. exp. Med., 148, 41-47.

27) Saito, K., Parker, B.W. \& Menzel, D.B. (1982) Disruption of phospholipid metabolism by paraquat in cultured pneumocytes. J. Toxicol environ. Health, 9, 527-534.

28) Schoenberger, C.L., Rennard, S.I., Bitterman, P.B., Fukuda, Y., Ferrans, V.J. \& Crystol, R.G. (1984) Paraquat induced pulmonary fibrosis. Role of the alveolitis in modulatiing the development of fibrosis. Amer. Rev. res. Dis., 129, 168-173.

29) Seidenfeld, J.J., Wycoff, D., Zavala, D.C. \& Richerdson, H.B. (1978) Paraquat lung injury in rabbit. Brit. J. ind. Med., 35, 245-257.

30) Smith, L.L. \& Rose, M.S. (1977) Biochemical changes in lung exposed to paraquat. In : Biochemical Mechanisms of Paraquat Toxicity, edited by A.P. Autor, Academic Press, New York, pp. 187-199. 
31) Smith, L.L., Rose, M.S. \& Wyatt, L. (1979) The pathology and biochemistry of paraquat. In: Oxygen Free Radicals and Tissue Damage (Chiba Foundation Symposium No. 65), Excerpta Medica, Amsterdam, pp. 321-341.

32) Smith, M., Turner, B.M., Tanigaki, N. \& Hirschhorn, K. (1978) Regional localization of HLA, $\mathrm{ME}_{\mathrm{s}}$ and $\mathrm{SOD}_{\mathrm{M}}$ on chromosome 6. Cytogenet. Cell Genet., 22, 428-433.

33) Trush, M.A., Mimnaugh, E.D., Ginsberg, E. \& Gram, T.E. (1981) In vitro stimulation by paraquat of reactive oxygen-mediated lipid peroxidation in rat microsomes. Toxicol. appl. Pharmacol., 60, 279-286. 